\title{
The volcanic activity at the Kuril Islands in 2019.
}

\author{
Artem V. Degterev* \\ Marina V. Chibisova
}

\author{
Institute of Marine Geology and Geophysics, FEB RAS, \\ Yuzhno-Sakhalinsk, Russia \\ *E-mail:d_a88@mail.ru
}

\begin{abstract}
Rus PDF }}$
Volcanic activity in the Kuril Islands in 2019 is presented on the grounds of the results of satellite and visual observations. In 2019 Ebeko (Paramushir Island, Northern Kuril Islands) and Raikoke (Raikoke Island, Central Kuril Islands) volcanos have erupted. Ebeko volcano was characterized by a manifestation of moderate explosive activity, being in such state since October of 2016. According to the surveillance camera, there were more than 565 emissions (in the daytime in the absence of cloudiness and fog) from 1.5 to $5 \mathrm{~km}$ above sea level, of which 63 are explosions with a height of 3 to $5 \mathrm{~km}$ above sea level. Periodically, ashfalls were observed on the territory of the city of Severo-Kurilsk. As compared to 2018 there was a slight decrease in activity on the volcano. From 21 June to 25 June of 2019 took a place a powerful (VEI - 4) explosive eruption of Raikoke volcano, which along with the volcanic eruption of Sarychev Peak volcano in June 2009 became one of the strongest in the Kuril Islands in the current century. The active phase of the eruption lasted about 15 hours - from 18:00 UTC on 21 June to 09:00 UTC on 22 June of 2019. During this time, separate volcanic explosions were observed (at least 9) and the phase of continuous supply of pyroclastic material ( 3.5 hours - 22:30 UTC on June 21 to 02:00 UTC on June 22). According to VAAC Tokyo, the maximum emission height exceeded $13 \mathrm{~km}$ above sea level, while the total area of the ash cloud formed as a result of intense explosive activity of Raikoke volcano is estimated at $\sim 227$ thousand $\mathrm{km}^{2}$. Ash clouds of Raikoke volcano posed a real danger for airlines of the Northwest Pacific.
\end{abstract}

\section{Keywords}

Kuril Islands, volcano, ash, monitoring of volcanic activity, eruption, satellite methods

For citation: Degterev A.V., Chibisova M.V. The volcanic activity at the Kuril Islands in 2019. Geosystems of Transition Zones, 2020, vol. 4, no. 1, p. 93-102. (In Russian). https://doi.org/10.30730/25418912.2020.4.1.093-102

Для цитирования: Дегтерев А.В., Чибисова М.В. Вулканическая активность на Курильских островах в 2019 г. Геосистемы переходных зон. 2020. Т. 4, № 1. С. 93-102.

https://doi.org/10.30730/2541-8912.2020.4.1.093-102

\section{References}

1. Avdeiko G.P., Antonov A.Iu., Volynets O.N. et al. 1992. Podvodnyi vulkanizm i zonal'nost' Kuril'skoi ostrovnoi dugi [Undersea volcanism and zonality of the Kuril island arc]. Moscow: Nauka Publ., 528 p.

2. Chibisova M.V., Degterev A.V. 2019. The activity of the Kurile volcanoes in 2018. Vestnik KRAUNTs. Nauki o Zemle = Bull. of Kamchatka Regional Association "Educational-Scientific Center". Earth Sciences, 1(41): 91-98. https://doi.org/10.31431/1816-5524-2019-1-41-91-98 
3. Degterev A.V., Chibisova M.V. 2019. The eruption of Raikoke volcano in June of 2019 (Raikoke Island, Central Kuril Islands). Geosistemy perekhodnykh zon = Geosystems of Transition Zones, 3(3): 304-309. doi.org/10.30730/2541-8912.2019.3.3.304-309

4. Efremov V.Yu., Girina O.A., Kramareva L.S., Loupian E.A., Manevich A.G., Melnikov D.V., Matveev A.M., Proshin A.A., Sorokin A.A., Flitman E.V. 2012. Creating an Information Service "Remote Monitoring of Active Volcanoes of Kamchatka and the Kuril Islands". Sovremennye problemy distantsionnogo zondirovaniia Zemli iz kosmosa [Modern problems of the Earth remote sounding from the space], 9(5): 155-170.

5. Fedorchenko V.I., Abdurakhmanov A.I., Rodionova R.I. 1989. [Volcanism of the Kuril Island arc: geology and petrogenesis]. Moscow: Nauka, $237 \mathrm{p}$.

6. Gordeev E.I., Girina O.A., Lupyan E.A., Sorokin A.A., Kramareva L.S., Efremov V.Y., Kashnitskii A.V., Uvarov I.A., Burtsev M.A., Romanova I.M. et al. 2016. The VolSatView information system for monitoring the volcanic activity in Kamchatka and on the Kuril Islands. J. of Volcanology and Seismology, 10(6): 382394. https://doi.org/10.1134/s074204631606004x

7. Gorshkov G.S. 1967. [Volcanism of the Kuril island arc]. Moscow: Nauka, 288 p.

8. Kirsanov I.T., Serafimova E.K., Sidorov S.S. et al. 1964. [Eruption of the Ebeko volcano in the March-April of 1963]. Biulleten' vulkanol. stantsii [Bulletin of Volcanological Stations], 36: 66-72.

9. Kotenko T.A., Kotenko L.V. 2018. [Reality of the hazard of lahars avalances at Severo-Kurilsk city on the example of 4 September of 2017 in the basins of Kuzminka and Matrosskaya rivers (Paramushir Island)]. In: Vulkanizm i sviazannye s nim protsessy: Materialy XXI region. nauch. konf., posviashch. Dniu vulkanologa, 29-30 marta $2018 \mathrm{~g}$. [Volcanism and associated processes: Materials of the XXI Scientific conference devoted to the Day of volcanologist, 29-30 March 2018]. Petropavlovsk-Kamchatsky: In-t vulkanologii i seismologii DVO RAN [Inst. of Volcanology and Seismology of the FEB RAS], 56-59.

10. Kotenko T.A., Kotenko L.V., Shapar' V.N. 2007. Increased activity on Ebeko Volcano, Paramushir I., North Kurils, in 2005-2006. J. of Volcanology and Seismology, 1(5): 285-295. https://doi.org/10.1134/s0742046307050016

11. Kotenko T.A., Kotenko L.V., Sandimirova E.I. et al. 2010. [Eruption of Ebeko volcano in January-June of 2009]. Vestnik KRAUNTs. Nauki o Zemle = Bull. of Kamchatka Regional Association "Educational-Scientific Center". Earth Sciences, 1(15): 56-68.

12. Kotenko T.A., Kotenko L.V., Sandimirova E.I. et al. 2012. [Eruptive activity of Ebeko volcano in 2010-2011 (Paramushir Island)]. Vestnik KRAUNTs. Nauki o Zemle = Bull. of Kamchatka Regional Association “Educational-Scientific Center". Earth Sciences, 1(19): 160-167.

13. Kotenko T.A., Sandimirova E.I., Kotenko L.V. 2018. The 2016-2017 eruptions of Ebeko volcano (Kuriles Islands). Vestnik KRAUNTs. Nauki o Zemle = Bull. of Kamchatka Regional Association "EducationalScientific Center". Earth Sciences, 1(37): 32-42.

14. Martynov Iu.A., Rybin A.V., Degterev A.V., Ostapenko D.S., Martynov A.Iu. 2015. Geochemical evolution of volcanism of the Matua Island in the Central Kurils. Russian J. of Pacific Geology, 9(1): 11-21. https://doi.org/10.1134/s1819714015010042

15. Meniailov I.A., Nikitina L.P., Khramova G.G. 1969. [Gas and hydrothermal eruption of Ebeko volcano in February-April of 1967]. Biulleten' vulkanol. stantsii [Bulletin of Volcanological Stations], 45: 3-6.

16. Meniailov I.A., Nikitina L.P., Budnikov V.A. 1992. [Activity of Ebeko volcano in 1987-1991 yr.: eruptions character, features of their products, hazard for Severo-Kurilsk city]. Vulkanologiia i seismologiia $=$ Volcanology and Seismology, 5-6: 21-33.

17. Noveishii i sovremennyi vulkanizm na territorii Rossii [Latest and modern volcanism on the territory of Russia]. 2005. Moscow: Nauka, 604 p.

18. Polonskii A.S. 1994. Kuriles. Kraevedcheskii Biulleten' [Regional Bulletin], 3: 3-86.

19. Rashidov V.A., Anikin L.P. 2018. Fieldworks at Alaid volcano in 2018, Atlasov Island, the Kuriles. Vestnik KRAUNTs. Nauki o Zemle = Bull. of Kamchatka Regional Association "Educational-Scientific Center". Earth Sciences, 3(39): 105-113. https://doi.org/10.31431/1816-5524-2018-3-39-105-113

20. Rashidov V.A., Anikin L.P. 2019. Fieldworks at Alaid volcano in 2019, Atlasov Island, the Kuriles. Vestnik KRAUNTs. Nauki o Zemle = Bull. of Kamchatka Regional Association "Educational-Scientific Center". Earth Sciences, 3(43): 109-115. https://doi.org/10.31431/1816-5524-2019-3-43-109-115

21. Rashidov V.A., Girina O.A., Ozerov A.Yu., Pavlov N.N. 2019. The June 2019 eruption of Raikoke volcano (the Kurile Islands). Vestnik KRAUNTs. Nauki o Zemle = Bull. of Kamchatka Regional Association “Educational-Scientific Center". Earth Sciences, 2(42): 5-8. doi:10.31431/1816-5524-2019-2-42-5-8

22. Rybin A.V., Chibisova M.V., Degterev A.V. 2017. The 2016 activity of the Kurile Islands volcanoes. Vestnik KRAUNTs. Nauki o Zemle = Bull. of Kamchatka Regional Association "Educational-Scientific Center". Earth Sciences, 1(33): 83-88. 
23. Rybin A.V., Chibisova M.V., Degterev A.V. 2018a. The 2017 activity of the Kurile Islands volcanoes. Vestnik KRAUNTs. Nauki o Zemle = Bull. of Kamchatka Regional Association "Educational-Scientific Center". Earth Sciences, 2(38): 102-109. https://doi.org/10.31431/1816-5524-2018-2-38-102-109

24. Rybin A.V., Chibisova M.V., Degterev A.V. 2018b. Monitoring of volcanic activity in the Kurile Islands: 15 years of work SVERT group. Geosistemy perekhodnykh zon = Geosystems of Transition Zones, 2(3): 259-266. https://doi.org/10.30730/2541-8912.2018.2.3.259-266

25. Skripko K.A., Fil'kova E.M., Khramova G.G. 1966. [State of Ebeko volcano in summer of 1965]. Biulleten' vulkanol. stantsii [Bulletin of Volcanological Stations], 42: 42-55.

26. Snou G. 1992. [Notes on the Kuril Islands]. Kraevedcheskii biulleten' [Regional Bulletin], 1: 89-127.

27. Tanakadate H. 1925. The volcanic activity in Japan during 1914-1924. Bulletin Volcanologique, 1(3): 3-19. 